\title{
Brand Placement in Music Videos: Artists, Brands and Products Appearances in the Billboard Hot 100 from 2003 to 2016
}

\section{Cande Sánchez-Olmos \& Araceli Castelló-Marínez}

To cite this article: Cande Sánchez-Olmos \& Araceli Castelló-Marínez (2020): Brand Placement in Music Videos: Artists, Brands and Products Appearances in the Billboard Hot 100 from 2003 to 2016, Journal of Promotion Management, DOI: 10.1080/10496491.2020.1745986

To link to this article: https://doi.org/10.1080/10496491.2020.1745986

曲 Published online: 12 Apr 2020.

Submit your article to this journal $₫$

View related articles \lceil

View Crossmark data $[\pi$ 


\title{
Brand Placement in Music Videos: Artists, Brands and Products Appearances in the Billboard Hot 100 from 2003 to 2016
}

\author{
Cande Sánchez-Olmos (D) and Araceli Castelló-Marínez \\ University of Alicante, Alacant, Spain
}

\begin{abstract}
The aim of this paper is to analyze the presence of artists, brands and products in music videos in the best-selling songs; the Billboard Hot 100 from 2003 to 2016. Using a content analysis, we look at 420 music videos at the top of the chart and which artists had more placements, what kind of brands and products were more likely to be linked to music, and the ratio of appearances between placements, brands and products. Firstly, some artists repeatedly appeared at the top of the chart, thereby implying there is a high concentration of a few pop stars in the chart (Rihanna, Katy Perry, Beyoncé and Bruno Mars and Taylor Swift) and Chris Brown was the artist with the highest number of placements. Secondly, results show that Adidas, Nike and Chevrolet are the most brands placed.
\end{abstract}

\section{KEYWORDS}

Marketing; communication; advertising; brand placement; music videos; record industry; Billboard Hot 100

\section{Introduction}

The main aim of this paper was to research brand placement, a communication technique which consists in strategically blending a brand or service into an audio-visual entertainment contents service so that the audience creates positive associations about the brand (Hudson \& Hudson, 2006; Lehu, 2007). Brand placement is becoming ever more important in the record industry because musicians have found it to be an alternative means of boosting their sales, especially after the digital crisis the industry has undergone. In fact, this technique is in constant growth. In 2017 brand placement income in the USA grew by $14 \%$, which in absolute terms comes to 15680 million dollars (PQ Media, 2018). According to this report, television is the channel where most brand placement income is received.

However, what motivated this research was the finding that videoclips and digital platforms showed twice as much growth. In this respect, if we look at the 100 most viewed videos on YouTube, 90 are videoclips and the

CONTACT Cande Sánchez-Olmos cande.sanchez@ua.es; Araceli Castelló-Martínez araceli.castello@ua.es E University of Alicante, Communication and Social Phychology, Carrertera San Vicente del Raspeig $S / N$, Alacant, 03690 Spain. 
rest are for children, many of which are music videos (YouTube, 2018). In light of these figures, this paper provides insights for expanding the analysis about who are at the top of the chart, the artists with most placements in their videoclips, the presence of brands and categories of products in music videos. Although this research is fundamentally exploratory and descriptive, it provides an overview of the relationship between artists, brands and products portrayed from 2003 until 2016.

For the record industry, being at the top of this chart means more profit (Parker, 1991) which ensures the musical future of artists. Therefore, on analyzing this data, we will know who has been at the top of the charts and what type of relationship they have had with the brands they act as influencers for. Brand placement in the Billboard Hot 100 should be analyzed as in this advertising technique the implication is the target audience has seen advertising without being aware of whether it was for commercial purposes or not.

In addition, and according to the musicologist perspective, music plays an important role in our society because, as Straw points out (2001), music is one of the key identity symbols which young people use to differentiate themselves from others. Furthermore, according to Frith (1996), music constructs our sense of identity through experiences which let us imagine ourselves in cultural narratives. Together, these academics stress how important music is in our lives, and this is why the brand influencer role artists have in music videos should be analyzed. In this respect, what effects music videos have had in the age of the internet must be studied in context. Traditionally, a videoclip has been thought of as a by-product of a musical recording aimed at selling a song (Goodwin, 1993; Vernallis, 2004; Viñuela, 2009), although it has always been used as a vehicle for advertising products which have been blended into the music video narrative (Englis, 1991; Goodwin, 1993). Moreover, with the rise of MTV, brands found clips to be excellent ways to showcase their products. However, with YouTube, videoclips no longer relied on the television media and, as a result, record labels opened their own channel networks on YouTube in order to make videoclips profitable.

\section{Review of literature}

\section{Brand placement in music videos}

There is a large and growing body of literature on how this communication technique has been applied. Generally speaking, the most outstanding contributions are those made by Galician (2004), Hudson and Hudson (2006), Karrh (1998) and Lehu (2007) to quote a few authors. Several studies in which brand placement has been researched have been carried out on 
cinema, TV and music. In terms of quantitative data, what is most noteworthy is the contents analysis of cinema by Galician and Bourdeau (2004), television by Smit et al. (2009), and music (Thornton and Burkhalter, 2015). As regards the effects, attitudes and responses the audience has to brand placement in music, research by Burkhalter and Thornton (2014), Ferguson and Burkhalter (2015) and Krishen and Sirgy (2016) show the positive effects this technique has had according to different variables.

Conversely, Sung and De Gregorio (2008) conclude that people reject brand placement more in music and video games than in cinema and television. In the same critical vein Pérez-Rufí et al. (2014) and Sánchez-Olmos (2018) found that rather than blending into the videoclips, brands impose themselves on them, which detracts from the argument that the music video is an expression of artistic post-modernism. In turn, other researchers (Soba and Aydin, 2013) question how ethical product placement is, claiming it to be an intrusive way of communicating with viewers.

Research into brand placement has been carried out in different categories of products over the last decade. Galician and Bourdeau (2004) observed how product placement evolved in 1977, 1987 and 1997 in 15 of the highest earning American films. They found the kind of products which most appeared in films were cars, beer, soft drinks and liquors. As for brands, Coke, Mercedes, Miller, Chevy, Pepsi-Cola Schlitz, BMW, Jack Daniels, Cadillac and CNN were the most seen ones. Another reference is that carried out by Thornton and Burkhalter (2015) on hip hop videoclips, in which the categories with most product placements were cars $(54.7 \%)$, then clothing/shoes (17.4\%), spirits (9.3\%) and jewelry (6.7\%). Lastly, there were similar findings in one piece of research (Sánchez-Olmos, 2018) on branded content in music. The categories of products most involved in branded content were clothing (25\%), drinks (beer and soft drinks) which together represented $34 \%$ of the total, and cars (10\% of the sample). Thus, this paper extends the research about what kind of brands and products were more likely to be linked to music, and the ratio of appearances between placements, brands and products. In addition, we will observe who were at the top of the chart and which artists had more placements.

\section{Billboard hot 100}

The Billboard Hot 100 chart shows the week's most popular songs across all genres, ranked by radio airplay audience impressions as measured by Nielsen Music, sales data as compiled by Nielsen Music and streaming activity data provided by online music sources. The chart is significant in that the higher the position a song reaches in it, the more media exposure it will obtain and therefore the more successful it will be. In this respect, 
the Billboard Hot 100 chart goes back to 1934, but the one we know today has been running since 1958 and is backed by large multinational American record companies, which means they influence other markets.

Regarding the importance of these lists, as Parker (1991, p. 216) pointed out "charts are essentially modernist reflections of capitalist practice, but the impact of romantic discourses of the artist can be seen in their mythological structure". For this author, charts, such as the Billboard Hot 100, not only work to create a sense of belonging amongst young people, but also reflect capitalist practices and reinforce the misconception that everyone, as they are free to purchase and choose music, can launch their favorite artist to the top of the charts. In the record industry, producers do not know beforehand how consumers are going to react to songs. That is, just $10 \%$ of the songs released are successful and these finance the other ones, so artists have become the bed fellows of the music industry. While Parker (1991) from a critical perspective considered consumers choice was not democratic, musicologists as Negus (1999) and Straw (2001) stressed the popularity and success of any given artist or recording song is notoriously difficult to predict because consumption of popular music has long been seen as incomprehensible.

If we carry out a diachronic analysis and see the artists and music genres which have most succeeded in the Hot 100 Billboard throughout its 60 years of history, we mainly find superstar artists. The top 10 artists with most number ones in this chart are headed by The Beatles, followed by Madonna, Elton John, Elvis Presley, Mariah Carey, Stevie Wonder, Janet Jackson, Michael Jackson, Whitney Houston and Rihanna in tenth position. There are a range of artists who perform different styles of pop and rock music. Ordanini and Nunes (2016) examined how the number of songs and artists appearing annually in the Billboard Hot 100 singles chart changed between 1974 and 2013 and concluded the evolution of recorded music technology has changed the charts when in the past there were fewer hits by many pop stars and now there are more hits by fewer superstars. In other words, concentration of superstars in popular music has been a trend since 2003 and even the biggest stars require more than a year to be successful.

In the period (2003-2016) important changes have taken place both in the record industry and in advertising. Consumers have started to reject traditional interruptive advertising; so, brands began blending their products into videoclips in order to absorb the values of the artist. In addition, brands help to fund videoclips in the record industry. Although both parties gain by this, Klein (2009) considers this partnership between the record industry and advertisers could be more parasitical than philanthropic if musicians depend on brands at the price of losing their freedom and creativity. 
Table 1. Sample.

\begin{tabular}{lc}
\hline No of analysis units per year & 30 \\
Total No of analysis units & 420 \\
No of years & 14 \\
Period & From 2003 to 2016 \\
\hline
\end{tabular}

Source: prepared by the author.

From the perspective of the music industry, the former business model based on selling singles and albums is no longer enough. Due to the impact of new technologies, production, promotion and distribution of music has changed as, advertising, streaming, digital music, live music and video streaming have all emerged as new sources of revenue. In other words, before seeing a return to growth in 2015, the global recording industry lost nearly 40\% in revenue from 1999 to 2014 (IFPI, 2017).

The purpose of this type of advertising is to make the brands more accessible to consumers in order to engage with them and their life styles (Meier, 2011), rather than to raise sales. This is because the impact of new technologies has also affected the advertising sector. Firstly, multiple entertainment platforms have evolved for winning over dispersed, demanding and disloyal users. Secondly, as consumer are saturated by advertising, they have come to reject traditional commercials. All this brings us to the notion that the real challenge the advertising industry faces is not technology or new media, but consumers themselves, who avoid intrusive messages and prefer experiences which are useful, important and negotiable, such as those found in videoclips.

\section{Method}

The main aim of this research is to analyze brand placements in music videos from 2003 up to 2016. More specifically, we observed what brands and products were placed by artists in this period. At this point, we had the following secondary objectives:

- To identify the main artists ranked in the Billboard Hot 100.

- To observe what brands and what categories of products were most placed in the music videos.

- To find out the ratio of appearances between placements, brands and products, music videos and years.

In this study, content analysis was used for carrying out this research. The sample was: the top thirty positions in each annual ranking of the Billboard Hot 100 chart from 2003 to 2016, which came to a total of 420 music videos (Table 1). This is a purposive non-probability sample that was selected according to the aims of this study. The unit of analysis was 
the entire music video. Each individual appearance of a brand, product or service whether seen, mentioned, or used was registered. A coder with a highly experience in collecting data on brands coded all the music videos based on the same set of variables developed by the research team together with the coder. According to the aims of this study, the variables were: artist name, song, title, product or service, and name of the brand. The sample was recorded for three months in 2017; from September to November.

All data was collected manually and entered into Excel. Brands were identified by their logo or if their name was visible, through recognition of unique branding (e.g.: triple stripe pattern on Adidas jacket or red soles for Christian Louboutin shoes) or extensive research online. The criteria for what brands were included was any recognizable branded consumer product except firearms. Any plain products that lacked distinctive features linking them to a brand or any other non-consumer product were excluded. For some data we were unable to identify any brand, whereby the brand variable was simply marked with the symbol "?". However, the product variable was coded indicating the product represented. For instance, in the music video "Work" (2016) by Rihanna a Land Rover was identified as well as two more cars whose brands were unrecognizable which were coded as products. Unrecognizable brands accounted for about $20 \%$ of the data but were included to give macro statistics on total brand visibility.

Regarding brand inclusion criteria, we made no distinction between brands that just happened to be used in a music video and those that were placed as a result of a prior agreement between the brands and content producers. However, it is broadly accepted in the industry, that the term "product placement" encompasses any appearance by a brand in entertainment, especially if it is mainstream. Furthermore, it is difficult to know whether placements are organic or if they have been paid for unless the producer of every individual music video is contacted.

Although there are several intra-coder checks to ascertain reliability, we use a percentage of agreement. Thus $10 \%$ of the sample was reanalyzed by the first author of this study and overall, I agreed $92 \%$ of the time with the experienced coder. Brands were coded by their names and products by their signifiers. The coder and author agreed on the products signifier.

\section{Results}

\section{Artists}

Firstly, 216 different artists accounted for the 420 songs, which came to an average of 1.94 songs per artist. However, 20.2\% of the songs represented only 10 artists, which means the same ones were highly concentrated at the top of the chart: Rihanna (with 16 songs), Katy Perry (10 songs), Beyoncé, 
Table 2. Ranking of artists of the sample units.

\begin{tabular}{llcccc}
\hline & \multicolumn{1}{c}{ Artist } & Songs & \% of total sample & Accumulated & $\%$ accumulated \\
\hline 1 & Rihanna & 16 & $3.8 \%$ & 16 & $3.8 \%$ \\
2 & Katy Perry & 10 & $2.4 \%$ & 26 & $6.2 \%$ \\
3 & Beyoncé & 8 & $1.9 \%$ & 34 & $8.1 \%$ \\
4 & Bruno Mars & 8 & $1.9 \%$ & 42 & $10.0 \%$ \\
5 & Taylor Swift & 8 & $1.9 \%$ & 50 & $11.9 \%$ \\
6 & Drake & 7 & $1.7 \%$ & 57 & $13.6 \%$ \\
7 & Justin Timberlake & 7 & $1.7 \%$ & 64 & $15.2 \%$ \\
8 & Maroon 5 & 7 & $1.7 \%$ & 71 & $16.9 \%$ \\
9 & The Black Eyed Peas & 7 & $1.7 \%$ & 78 & $18.6 \%$ \\
10 & Usher & 7 & $1.7 \%$ & 85 & $20.2 \%$ \\
11 & 50 Cent & 6 & $1.4 \%$ & 91 & $23.7 \%$ \\
12 & Chris Brown & 6 & $1.4 \%$ & 97 & $24.5 \%$ \\
13 & Flo Rida & $1.4 \%$ & 103 & $26.0 \%$ \\
14 & Lady Gaga & $1.4 \%$ & 114 & $27.1 \%$ \\
15 & Adele & 6 & 1.2 & 119 & $28.3 \%$ \\
16 & Fergie & 5 & 1.2 & 124 & $29.5 \%$ \\
17 & Kelly Clarkson & 5 & 1.2 & 128 & $30.5 \%$ \\
18 & Eminem & 5 & $1.0 \%$ & 132 & $31.4 \%$ \\
19 & Kanye West & 4 & $1.0 \%$ & 136 & $32.4 \%$ \\
20 & Miley Cyrus & 4 & $1.0 \%$ & & \\
\hline
\end{tabular}

Source: prepared by the author.

Table 3. Artists with more than one title per year.

\begin{tabular}{lllcccc}
\hline & & \multicolumn{1}{c}{ Artist } & Songs & $\begin{array}{c}\% \text { of annual } \\
\text { sample }(30)\end{array}$ & Accumulated & $\%$ accumulated \\
\hline 1 & 2004 & Usher & 4 & $13.3 \%$ & 4 & $1.0 \%$ \\
2 & 2015 & Taylor Swift & 4 & $13.3 \%$ & 8 & $1.9 \%$ \\
3 & 2003 & 50 Cent & 3 & $10.0 \%$ & 11 & $2.6 \%$ \\
4 & 2005 & 50 Cent & 3 & $10.0 \%$ & 14 & $3.3 \%$ \\
5 & 2005 & Kelly Clarkson & 3 & $10.0 \%$ & 17 & $4.0 \%$ \\
6 & 2007 & Akon & 3 & $10.0 \%$ & 20 & $4.8 \%$ \\
7 & 2007 & Fergie & 3 & $10.0 \%$ & 23 & $5.5 \%$ \\
8 & 2008 & Chris Brown & 3 & $10.0 \%$ & 26 & $6.2 \%$ \\
9 & 2008 & Rihanna & 3 & $10.0 \%$ & 29 & $6.9 \%$ \\
10 & 2011 & Bruno Mars & 3 & $10.0 \%$ & 32 & $7.6 \%$ \\
11 & 2011 & Katy Perry & 3 & $10.0 \%$ & 35 & $8.3 \%$ \\
12 & 2012 & Flo Rida & 3 & $10.0 \%$ & 38 & $9.0 \%$ \\
13 & 2013 & Bruno Mars & 3 & $10.0 \%$ & 41 & $9.8 \%$ \\
14 & 2015 & The Weeknd & 3 & $10.0 \%$ & 44 & $10.5 \%$ \\
15 & 2016 & Drake & 3 & $10.0 \%$ & 47 & $11.2 \%$ \\
16 & 2016 & The Chainsmokers & 3 & $10.0 \%$ & 50 & $11.9 \%$ \\
17 & 2016 & Twenty One Pilots & 3 & $10.0 \%$ & 53 & $12.6 \%$ \\
18 & 2003 & Beyoncé & 2 & $6.7 \%$ & 55 & $13.1 \%$ \\
19 & 2003 & Fabulous & 2 & $6.7 \%$ & 57 & $13.6 \%$ \\
20 & 2004 & Alicia Keys & 2 & $6.7 \%$ & 59 & $14.0 \%$ \\
\hline
\end{tabular}

Source: prepared by the author.

Bruno Mars and Taylor Swift (each of whom had 8 songs) held the top positions in the artists ranking (Table 2).

Secondly, in terms of the ranking per year, we found 153 videoclips from artists who occupied more than one position. These artists represented $36.4 \%$ of the total sample. In other words, around one third of the songs were from artists who repeatedly appeared in the total ranking per year (Table 3). Amongst these, Usher and Taylor Swift in 2004 and 2015 


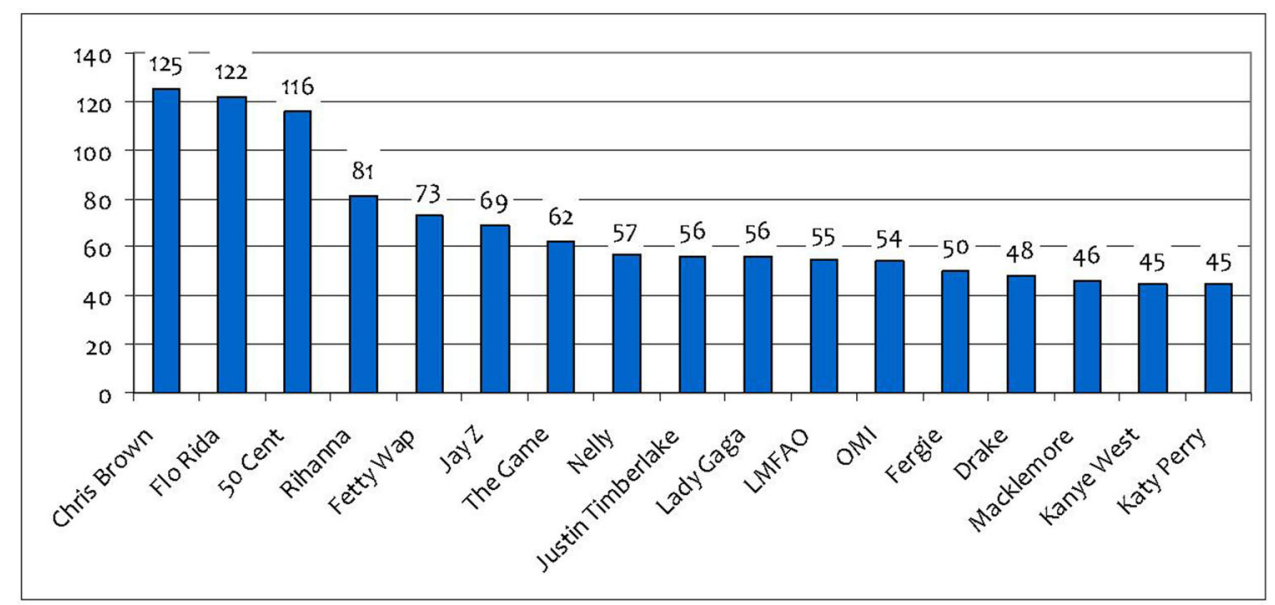

Figure 1. Artists chart according to the number of placements in their videoclips.

Source: prepared by the author

respectively, had four songs each, which accounted for $13.3 \%$ of the total annual sample (30 songs).

As for the partnership between superstars and brands, out of a total of 216 artists, $188(87 \%)$ of them displayed brands in their music videos. In this respect, Chris Brown, Flo Rida, 50 Cent, Rihanna, Fetty Wap and Jay $\mathrm{Z}$ were the artists with most placements in their videoclips $125,122,116$, 81,73 and 69 appearances respectively (Figure 1).

\section{Brands and categories of products}

In total, brands appeared 3183 times. On average, brand placements were identified in $84.5 \%$ of the sample (in 355 out of 420 music videos), representing a total of 3325 placements (Table 8). Music videos in which brands were not identified accounted for $15.5 \%$ of the sample. For instance, "Crazy" (2006) by Gnarls Barkley is a music video made by animation and abstract graphics where brands could not be identified. In addition, we coded products for $4.4 \%$ (146 units) of placements (3325) in these 355 music videos, but we were unable to identify any specific brand. Thus, around $20 \%$ of the total were unidentified brands.

The most placed ones in the sample (Table 4) were, Adidas (99 placements), Nike (98 placements), Chevrolet (84 placements) and NY Yankees (80 placements). Additionally, 59\% of the total number of brands coded (529) appeared just once, meaning that $16.6 \%$ of the total were placed just one time. Furthermore, $41 \%$ of the total (369) were placed more than once and appeared 2654 times which accounted for $83.4 \%$ of the total number of appearances. 
Table 4. Brands ranking with more than 20 appearances.

\begin{tabular}{llcccc}
\hline & \multicolumn{1}{c}{ Brand } & Appearances & $\begin{array}{c}\text { \% of total } \\
\text { appearances }\end{array}$ & Accumulated & $\%$ accumulated \\
\hline 1 & Adidas & 99 & $3.1 \%$ & 99 & $3.1 \%$ \\
2 & Nike & 98 & $3.1 \%$ & 197 & $6.2 \%$ \\
3 & Chevrolet & 84 & $2.6 \%$ & 281 & $8.8 \%$ \\
4 & NY Yankees & 80 & $2.5 \%$ & 361 & $11.3 \%$ \\
5 & Apple & 56 & $1.8 \%$ & 417 & $13.1 \%$ \\
6 & Ford & 56 & $1.8 \%$ & 473 & $14.9 \%$ \\
7 & New Era & 47 & $1.5 \%$ & 520 & $16.3 \%$ \\
8 & BMW & 46 & $1.4 \%$ & 566 & $17.8 \%$ \\
9 & MLB & $1.4 \%$ & 611 & $19.2 \%$ \\
10 & Beats by Dre & 43 & $1.4 \%$ & 654 & $20.5 \%$ \\
11 & Cadillac & 40 & $1.3 \%$ & 694 & $21.8 \%$ \\
12 & Mercedes-Benz & 36 & $1.1 \%$ & 730 & $24.9 \%$ \\
13 & Lamborghini & 35 & $1.1 \%$ & 765 & $25.1 \%$ \\
14 & Air Jordan & 34 & $1.1 \%$ & 799 & $26.2 \%$ \\
15 & Nokia & 34 & $1.1 \%$ & 833 & $27.2 \%$ \\
16 & Converse & 33 & $1.0 \%$ & 866 & $28.2 \%$ \\
17 & Atlanta braves & 32 & $1.0 \%$ & 898 & $29.2 \%$ \\
18 & Versace & 30 & $0.9 \%$ & 928 & $30.0 \%$ \\
19 & Rolls-Royce & 28 & $0.9 \%$ & 956 & $30.9 \%$ \\
20 & Dodge & 26 & $0.8 \%$ & 982 & $31.6 \%$ \\
21 & Yamaha & 24 & $0.8 \%$ & 1006 & $32.3 \%$ \\
22 & Gucci & $0.7 \%$ & 1028 & $33.0 \%$ \\
23 & LA Dodgers & 22 & $0.7 \%$ & 1050 & $33.6 \%$ \\
24 & Gibson & 22 & $0.7 \%$ & 1071 & $34.3 \%$ \\
25 & G-Unit & 21 & $0.7 \%$ & 1092 & $35.0 \%$ \\
26 & Louis Vuitton & 21 & $0.7 \%$ & 1113 & $35.6 \%$ \\
27 & Timberland & 21 & $0.7 \%$ & 1134 &
\end{tabular}

Source: prepared by the author.

Now, looking at the brands and products seen in the videoclips, we found 898 different brands which appeared 3183 times (averaging 3.55 appearances per brand) and 278 different products were placed 3325 times (averaging 11.96 placements per product). The reason why there were more products than brand appearances is because a brand can place different products. For instance, Adidas placed 3 different products: shoes, sport bras and jackets in the music video "Fancy" (2014) by Iggy Azalea.

As for the products, 230 different objects or services were registered according to their signifiers. Table 5 shows a list with forty different products which have appeared in at least $0.3 \%$ of the sample (11 to 9 placements). The most popular product was the car with 608 placements $(18.3 \%$ of the total). Cups came second with 357 placements $(10.8 \%)$ followed by shoes with 277 placements (8.4\%).

In addition, Table 6 shows a list of the 125 products most placed ranked by the number of times they were placed. Despite the diversity of products coded, two group can be observed. First, accessories (caps, shoes, sun glasses, watches, hats, jewelry, glasses, belts, etc.) accounted for $23.4 \%$ of the total number of placements (778). Second, clothing (jackets, t-shirts, jerseys, jeans, underwear, sweaters, tracksuits, polo t-shirts, jumpers, etc.) represented $13.4 \%$ of the total (446). Finally, two smaller groups related to 
Table 5. Products ranking with more than $0.3 \%$ appearances.

\begin{tabular}{|c|c|c|c|}
\hline & Product & Placements & $\%$ Of Total Placements \\
\hline 1 & Car & 608 & $18.3 \%$ \\
\hline 2 & Cap & 357 & $10.8 \%$ \\
\hline 3 & Shoes & 277 & $8.4 \%$ \\
\hline 4 & Instrument & 175 & $5.3 \%$ \\
\hline 5 & Jacket & 117 & $3.5 \%$ \\
\hline 6 & Sun glasses & 115 & $3.5 \%$ \\
\hline 7 & Mobile phone & 104 & $3.1 \%$ \\
\hline 8 & Jersey & 100 & $3.0 \%$ \\
\hline 9 & Bottle of alcoholic drink & 95 & $2.9 \%$ \\
\hline 10 & T-shirt & 79 & $2.4 \%$ \\
\hline 11 & Watch & 63 & $1.9 \%$ \\
\hline 12 & Headphones & 37 & $1.1 \%$ \\
\hline 13 & Amplifier & 31 & $0.9 \%$ \\
\hline 14 & Sparkling wine & 30 & $0.9 \%$ \\
\hline 15 & Beer & 29 & $0.9 \%$ \\
\hline 16 & Computer & 29 & $0.9 \%$ \\
\hline 17 & Motorbike & 27 & $0.8 \%$ \\
\hline 18 & Film & 25 & $0.8 \%$ \\
\hline 19 & Hat & 24 & $0.7 \%$ \\
\hline 20 & Jewelry & 23 & $0.7 \%$ \\
\hline 21 & Liquor & 19 & $0.6 \%$ \\
\hline 22 & App & 18 & $0.5 \%$ \\
\hline 23 & Jumper & 18 & $0.5 \%$ \\
\hline 24 & Mp3 player & 14 & $0.4 \%$ \\
\hline 25 & Glasses & 13 & $0.4 \%$ \\
\hline 26 & Jeans & 13 & $0.4 \%$ \\
\hline 27 & Underwear & 13 & $0.4 \%$ \\
\hline 28 & Belt & 12 & $0.4 \%$ \\
\hline 29 & Drink & 12 & $0.4 \%$ \\
\hline 30 & Magazine & 12 & $0.4 \%$ \\
\hline 31 & Sweater & 12 & $0.4 \%$ \\
\hline 32 & Tracksuit & 12 & $0.4 \%$ \\
\hline 33 & Camera & 11 & $0.3 \%$ \\
\hline 34 & Jet & 11 & $0.3 \%$ \\
\hline 35 & Polo shirt & 11 & $0.3 \%$ \\
\hline 36 & Microphone & 10 & $0.3 \%$ \\
\hline 37 & Neon sign & 10 & $0.3 \%$ \\
\hline 38 & Soda & 10 & $0.3 \%$ \\
\hline 39 & Speaker & 10 & $0.3 \%$ \\
\hline 40 & Website & 9 & $0.3 \%$ \\
\hline
\end{tabular}

Source: prepared by the author.

technology (7\% and 232 placements) and alcoholic drinks (4\% and 135) completed the most frequent product categories.

\section{Ratio of appearances between placements, brands and products}

We first found the products-brand ratio which gave us the relationship between both variables (Table 7) in percentage terms. In 29 cases $(6.9 \%$ of the sample) this was over $100 \%$. That means there were more products than brands, an example of which was "The Edge of Glory" (2011) by Lady Gaga, where just one brand (Versace) placed five different products, so the ratio was $500 \%$. In 138 units (32.9\%) the number of products and brands was on par, giving us a ratio of $100 \%$. Finally, in 188 cases $(44.8 \%)$ the 
Table 6. List of the 125 products most placed.

\begin{tabular}{|c|c|c|c|c|c|c|c|c|c|}
\hline \multicolumn{10}{|c|}{ Products } \\
\hline 1 & Car & 26 & Jeans & 51 & Hoodie & 76 & Tyre(s) & 101 & Casette \\
\hline 2 & Cap & 27 & Underwear & 52 & Casino & 77 & Advertising screen & 102 & Cigar(s) \\
\hline 3 & Shoes & 28 & Belt & 53 & Scooter & 78 & Attachable lens & 103 & Club \\
\hline 4 & Instrument & 29 & Drink & 54 & Shirt & 79 & Boat & 104 & Condom(s) \\
\hline 5 & Jacket & 30 & Magazine & 55 & Toy & 80 & Bodysuit & 105 & Costume \\
\hline 6 & Sun glasses & 31 & Sweater & 56 & Tv & 81 & Boombox & 106 & Crop top \\
\hline 7 & Mobile phone & 32 & Tracksuit & 57 & Earphones & 82 & Boots & 107 & Chain \\
\hline 8 & Jersey & 33 & Camera & 58 & Tracksuit bottoms & 83 & Bra & 108 & Character \\
\hline 9 & $\begin{array}{l}\text { Bottle of alcoholic } \\
\text { drink }\end{array}$ & 34 & Jet & 59 & Tv channel & 84 & Cartoon & 109 & Chemical \\
\hline 10 & T-shirt & 35 & Polo shirt & 60 & Water bottle & 85 & Coat & 110 & Chip(s) \\
\hline 11 & Watch & 36 & Microphone & 61 & Wine & 86 & Computer & 111 & Deodorant \\
\hline 12 & Headphones & 37 & Neon sign & 62 & Award & 87 & Credit/debit card & 112 & Drums \\
\hline 13 & Amplifier & 38 & Soda & 63 & Ball & 88 & Dressing gown & 113 & E-hookah \\
\hline 14 & Sparkling wine & 39 & Speaker & 64 & Building & 89 & Handbag & 114 & Exercise machine \\
\hline 15 & Beer & 40 & Website & 65 & Cereal & 90 & Monitor & 115 & Fashion show \\
\hline 16 & Computer & 41 & Shorts & 66 & Dj equipement & 91 & Phone & 116 & Headset \\
\hline 17 & Motorbike & 42 & Tablet & 67 & Energy drink & 92 & Store & 117 & Jewelry box \\
\hline 18 & Film & 43 & Bag & 68 & Fragrance & 93 & Tank top & 118 & Lip balm \\
\hline 19 & Hat & 44 & Comic book & 69 & Game & 94 & Venue & 119 & Luggage \\
\hline 20 & Jewelry & 45 & Food & 70 & Gloves & 95 & Video game & 120 & Make-up \\
\hline 21 & Liquor & 46 & Headband & 71 & Helicopter & 96 & Bank & 121 & Medication \\
\hline 22 & App & 47 & Helmet & 72 & Hotel & 97 & Bathroom product & 122 & Oil \\
\hline 23 & Jumper & 48 & Restaurant & 73 & Software & 98 & Bobblehead & 123 & Skateboard \\
\hline 24 & Mp3 player & 49 & Billboard & 74 & Sports team & 99 & Book & 124 & Skirt \\
\hline 25 & Glasses & 50 & Controller & 75 & TV Show & 100 & Cardigan & 125 & Swimwear \\
\hline
\end{tabular}

Source: prepared by the author.

number of products was less than the number of brands. In the rest of the music videos (15.5\%), brands were unidentified.

Secondly, the brand-placements ratio showed that in 113 instances the number of brands and placements coincided, while in the other 242 under $100 \%$ did, so, brands were placed several times per videoclip. For example, in the "Cold Water" (2016) videoclip by Major Lazer featuring Justin Bieber and $\mathrm{M} \varnothing$ there was a sole brand and product, but 6 placements, which were the dancers' jackets. In the products-placements ratio, we can see that in 74 units of the sample $(17.6 \%)$ the number of products matched the number of placements. In addition, in 281 videoclips (67\%) the number of placements surpassed that of the different products. In the remaining music videos (15.5\%) brands were unidentified. In Table 7 the videoclips ranking can be seen according to how many brand placements there were.

If we combine the information about the songs (year, ranking position and artist) with the placements identified (Table 7), we can see that the Chris Brown videoclip "Look at me" (2011) at position 21 was the song with the highest number of placements (48). This was followed by the videoclip "679" by Fetty Wap at position 21 from the 2015 chart and consistently by "Loyal" by Chris Brown at position 30 from the 2014 chart where 43 placements were identified.

As for the number of videoclips in terms of the number of placements in them (Table 8), we found three videoclips in which there were over 40 


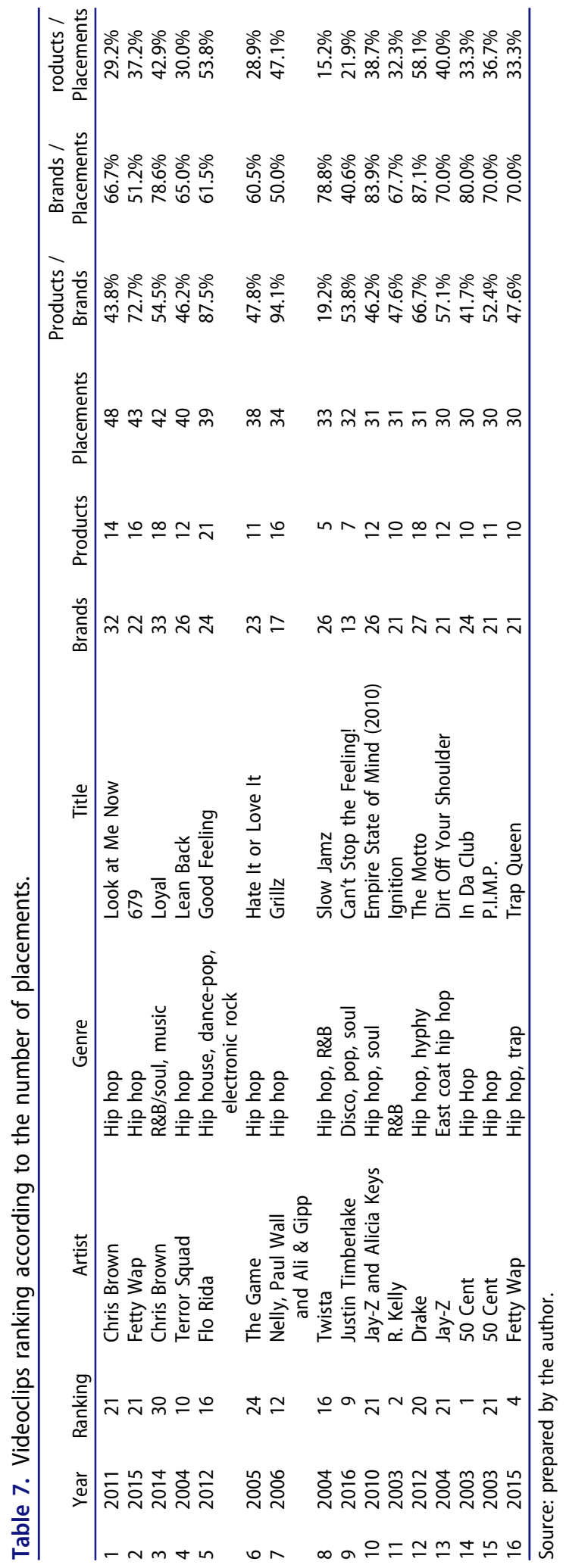


Table 8. Number of videoclips according to the number of placements.

\begin{tabular}{lcc}
\hline Placements & Videoclips & $\%$ of the sample \\
\hline Over 40 & 3 & $0.7 \%$ \\
From 31 to 40 & 9 & $2.1 \%$ \\
From 21 to 30 & 21 & $5.0 \%$ \\
From 11 to 20 & 81 & $19.3 \%$ \\
From 2 to 10 & 207 & $49.3 \%$ \\
1 & 34 & $8.1 \%$ \\
None & 65 & $15.5 \%$ \\
\hline
\end{tabular}

Source: prepared by the author.

Table 9. Placements per year.

\begin{tabular}{lccccc}
\hline & Year & $\begin{array}{c}\text { Songs with } \\
\text { appearances }\end{array}$ & $\begin{array}{c}\text { \% of annual } \\
\text { sample }\end{array}$ & Placements & \% of placements \\
\hline 1 & 2006 & 21 & $70.0 \%$ & 161 & $4.9 \%$ \\
2 & 2009 & 26 & $86.7 \%$ & 156 & $4.7 \%$ \\
3 & 2013 & 20 & $66.7 \%$ & 184 & $5.6 \%$ \\
4 & 2008 & 24 & $80.0 \%$ & 178 & $5.4 \%$ \\
5 & 2007 & 29 & $96.7 \%$ & 208 & $6.3 \%$ \\
6 & 2011 & 24 & $80.0 \%$ & 202 & $6.1 \%$ \\
7 & 2014 & 27 & $90.0 \%$ & 226 & $6.8 \%$ \\
8 & 2005 & 25 & $83.3 \%$ & 293 & $8.8 \%$ \\
9 & 2016 & 26 & $86.7 \%$ & 323 & $9.7 \%$ \\
10 & 2015 & 28 & $93.3 \%$ & 317 & $9.6 \%$ \\
11 & 2003 & 26 & $86.7 \%$ & 258 & $7.8 \%$ \\
12 & 2004 & 27 & $90.0 \%$ & 294 & $8.9 \%$ \\
13 & 2010 & 29 & $96.7 \%$ & 226 & $6.8 \%$ \\
14 & 2012 & 23 & $76.7 \%$ & 299 & $9.0 \%$ \\
15 & & 355 & $84.5 \%$ & 3325 & $100.3 \%$ \\
\end{tabular}

Source: prepared by the author.

placements. In the largest range in the sample $(49.3 \%)$ there were between 2 and 10 placements, whilst in $19.3 \%$ of the sample there were from 11 to 20 placements.

Thirdly, and considering the 355 music videos (84.5\% of the sample) where brands were recognizable, the total number of placements per annual ranking were summarized. Brand placements identified by annual ranking (Table 9) accounted for over $66 \%$ of the top 30 positions every year, and this figure even reached 90\% five times (2004, 2007, 2010, 2014 and 2015). In this respect, 2013 and 2006 were the years with least placements (66\% and $70 \%$ respectively). As for the number of placements per year, the highest figures were seen in 2015 and 2016 with 317 (9.6\%) and 323 (9.7\%) placements respectively (Table 9).

What is surprising is that the songs which reached the top positions were not necessarily those with the most placements (Figure 2). In fact, if we were to calculate the average number of placements per number of videoclips with placements in each annual ranking, we would see that the videoclips with most placements on average were those in positions $21,16,11$, 13 and 1 of the ranking, so products and brands appeared randomly and were not related to the ranking position. 


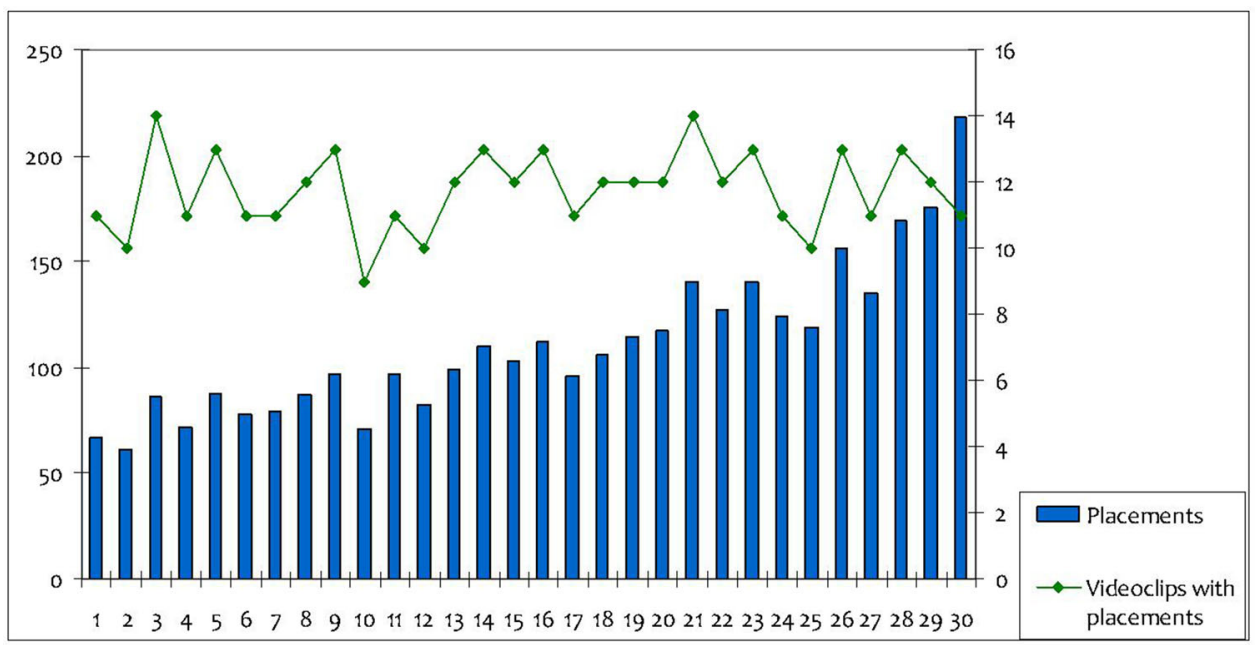

Figure 2. Number of placements and number of videoclips according to the annual ranking position.

Source: prepared by the author.

\section{Discussion}

Overall, these findings have helped us to understand the trend in brand placement in music videos, and more specifically to know which artists endorse brands and what kind of brands and products are more likely to be linked to music. These findings confirmed the record industry and brands go hand in hand; in 355 out of a total of 420 videoclips analyzed, (84.5\%) brands appear. Therefore, seemingly, in general, it is hard to avoid brand placements when watching music videos. For the record industry, brands have merged as a new source of revenue: out of a total of 216 artists, 188 $(87 \%)$ of them displayed brands in their music videos. Our results confirmed a growing trend in using this technique, since in 2015 and 2016 the highest number of placements were seen (PQ Media, 2018). However, they also indicated how important brand placement was in 2004, a year marked by crisis in the record industry and in which, nevertheless, the greatest number of brands appeared in videoclips. Nevertheless, we cannot confirm any direct relationship between brand placement and the crisis in the record industry because there was an upturn in the music industry in 2015 and 2016, years that marked the highest number of brand placements.

Additionally, there were distinctive brand appearances in 2004, the year before YouTube was founded and which was the sixth consecutive year in which a fall in revenue for music companies was registered. This period heralded the start of a downward trend in income whose low point was 2011, after which 2012 marked an upturn, and it appeared to stabilize in 2016, according to how the data of the IFPI (2017) is interpreted. 
Secondly, the top positions of the chart are occupied by the same artists, which could imply, as Ordanini and Nunes (2016) stated, a concentration of superstars at the top of the chart since 2003 where fewer artists reached the top of the chart after music became digitalized. These results showed the artists who dominated the chart during this period, out of which Rihanna was the most successful, with 16 songs at the top. Not surprisingly, Rihanna has been one of the most important artists over the sixty years of the history of the Billboard Hot 100. In addition, the artists who most stood out were Usher and Taylor Swift in 2004 and 2015, respectively, each of whom had four songs these years. Thus, around one third of these songs researched were by artists who had repeat appearances in the chart year after year. This was more due to the tastes of fans had than to deliberate strategies set by multinationals. However, as Parker (1991) pointed out, consumer choices are first set by the music industry through marketing strategies, which could influence what tastes and values listeners have.

Regarding the second aim, (what brands and products were placed), our results matched the findings of a study carried out by Galician and Bourdeau (2004) in so far as brands such as Chevrolet, Mercedes and BMW were still the most placed ones. However, technology brands which had not appeared in previous research were identified in our analysis. These were Apple (position 5), Nokia (position 15) and the headphones of Beats by Dre from Apple (position 10). In addition, these were strongly connected to the world of music and the digital revolution it underwent in the period under study. Indeed, in 2003 iTunes was the first shop which sold digital songs and Nokia was the first telephone to provide a songs catalog in 2006.

As for the products, our results coincided with Burkhalter and Thornton (2014) and Sánchez-Olmos (2018); the car was one of the most placed products, accounting for $18.3 \%$ of the total. This is no wonder, as it is the vehicle which transports young people to parties-the symbol of liberty and individualism. Music is essential for attracting consumers because it provides the sound track to experiences associated with it. However, luxury car brands, such as Lamborghini and Rolls-Royce; or high-range German brands such as Mercedes and BMW were those which stood out the most.

Accessories and clothing, which accounted for $23.4 \%$ and $13.4 \%$ of the total, are fashion-related product categories and they go together especially well with music because, although they set some rules of thumb for social groups to abide by, they both leave room for individual tastes. Music and fashion are crucial to constructing people's identities and the cap, an identity symbol for young people and the way by which a person transmits his or her values and lifestyle, was the accessory which most appeared. This product was used by any sports brand such as Adidas (top 1), Nike 
(position 2), Air Jordan and Converse and in the videoclips the brands of teams in the baseball league acted as symbols of American identity. These brands established the differences, values and lifestyles of those who acted as influencers for and dressed these teams. This was seen in brands such as the NY Yankees (position 3), the Atlanta Braves (position 17) and MLB (position 9).

Finally, overall the ratio of products and brands was on par. However, some brands like Versace in "The Edge of Glory" (2011) by Lady Gaga placed five different products, where the ratio was 500\%. That means that there two types of brand placements in music videos. The first and most usual type is what we call "multi brand" and refers to music videos in which many different brands and products are placed, according to their link with the audio-visual narrative. The second and less common category is "exclusiveness", where just one brand places different products. In this event, the brand does not compete with other ones and the audience might engage more with it.

\section{Managerial implications}

This study's conclusions may help practitioners find out about brand placement in music videos. On one hand, these findings demonstrated that brands placed in music videos have evolved in harmony with trends in our lifestyles. On the other hand, there is no relationship between the top chart positions and the videoclips with the largest number of placements. In fact, those with most placements on average appear in the middle or at the end of the ranking. Due to the great difficulty the record industry has in predicting how successful a song will be (Negus, 1999; Straw, 2001), marketers cannot know in advance to what extent their brands might have an impact.

As for the most placed brands, our findings closely matched those from similar research in which cars, fashion (clothing, etc.) and accessories (cups, sun glasses, etc.) were the main categories of products involved in placements. Moreover, technology goods appeared with brands such as Apple or Nokia, whose expansion are symbolic of the change to a digital society. Thus, music videos are an attractive format for promoting (Goodwin, 1993) products like cars, fashion and technological brands. Furthermore, media convergence includes materials and actions which are difficult to classify from a traditional advertising perspective and creates situations in which the attention of the consumer is sought by experiences with the brand. In this context, as with the findings in this study, music videos are important for engaging consumers.

However, on a critical note, we may wonder if videoclips are at risk of being oversaturated by brands, especially if we bear in mind that the 
audience is unaware if placements are for commercial purposes or not. Despite the positive attitude the audience has toward product placements in the Burkhalter and Thornton (2014) videoclips, the results of this research show there to be an enormous number of brands in this content. Therefore, there must be a critical analysis of this technique since music is crucial to forming the values people have (Straw, 2001). Consequently, the line between music and advertising has become blurred since music videos work as a vehicle with which brands blend their products. This phenomenon refers to more than just music. Actually, it is known as musicvertising (a blend of music and advertising), a neologism which expresses the notion that music videos simultaneously encompass both the esthetics of music and the marketing goals of brands (Sánchez-Olmos, 2018). Thus, apart from promoting songs, just as observed by other researchers in the MTV period (Englis, 1991; Goodwin,1993) videoclips have become advertising media for promoting products, just as this research shows.

\section{Limitations of the study}

The shortcomings in this study is its exploratory and highly descriptive nature; it only describes artists, brands and categories of products but it does not delve into brand discernibility, nor why these categories of product were placed. Nevertheless, its strength is that not only does it cover an important number of years (from 2003 to 2016) but also a crucial period characterized by digital changes in the record industry. In fact, this study is the first step for carrying out more ambitious and deeper research in the future.

\section{Future research}

One important line of future research will be to analyze why the most watched music videos contain less brand placements. Furthermore, other studies could be made to analyze brand placements and different styles of music. On a final note, this study was part of a wider project whose future lines of research will focus on analyzing the way in which brands place products in narratives. The integration or imposition of brands in music videos could be analyzed according to the following variables: brand discernibility and visibility of the logo.

\section{ORCID}

Cande Sánchez-Olmos (D) http://orcid.org/0000-0001-5080-2835 


\section{References}

Burkhalter, J. N., \& Thornton, C. G. (2014). Advertising to the beat: Analysis of brand placements in hip-hop music videos. Journal of Marketing Communications, 20(5), 366-382. doi:10.1080/13527266.2012.710643

Englis, B. G. (1991). Music television and its influences on consumers culture, and the transmission of consumption messages. Advances in Consumer Research, 18(1), 111-114.

Ferguson, N. S., \& Burkhalter, J. N. (2015). Yo, DJ, That's my band: An examination of consumer response to brand placement in hip-hop music. Journal of Advertising, 44(1), 47-57. doi:10.1080/00913367.2014.935897

Frith, S. (1996). Performing rites: on the value of popular music. Oxford University Press.

Galician, M. L. (2004). Product placement in the 21st century. Journal of Promotion Management, 10(1-2), 241-258. doi:10.1300/J057v10n01_21

Galician, M. L., \& Bourdeau, P. G. (2004). The evolution of product placements in Hollywood cinema. Journal of Promotion Management, 10(1-2), 15-36. doi:10.1300/J057v10n01_03

Goodwin, A. (1993). Dancing in the distraction factory: music television and popular culture. Routledge.

Hudson, S., \& Hudson, D. (2006). Branded entertainment: A new advertising technique or product placement in disguise? Journal of Marketing Management, 22(5-6), 489-504. doi: $10.1362 / 026725706777978703$

IFPI. 2017. Digital Music Report. http://bit.ly/ifpi-2016.

Karrh, J. A. (1998). Brand placement: A review. Journal of Current Issues \& Research in Advertising, 20(2), 31-49. doi:10.1080/10641734.1998.10505081

Klein, B. (2009). As heard on TV: Popular music in advertising. Ashgate.

Krishen, A. S., \& Sirgy, M. J. (2016). Identifying with the brand placed in music videos makes me like the brand. Journal of Current Issues \& Research in Advertising, 37(1), 45-58. doi:10.1080/10641734.2015.1119768

Lehu, J. M. (2007). Branded Entertainment: product placement \& branded strategy in the entertainment business. Kogan Page Publishers.

Meier, L. M. (2011). Promotional ubiquitous music: Recording artists, brands, and "rendering authenticity". Popular Music and Society, 34(4), 399-415. doi:10.1080/03007766.2011.601569

Negus, K. (1999). Music genres and corporate cultures. Routledge. doi:10.4324/9780203169469

Ordanini, A., \& Nunes, J. C. (2016). From fewer blockbusters by more superstars to more blockbusters by fewer superstars. International Journal of Research in Marketing, 33(2), 297-313. doi:10.1016/j.ijresmar.2015.07.006

Parker, M. (1991). Reading the charts, making sense with the hit parade. Popular Music, 10(2), 205-217. doi:10.1017/S0261143000004517

Pérez-Rufí, J. P., Navarrete-Cardero, J. L., Gómez-Pérez, F. J. (2014). Product placement on music video: Content analysis of brand placement in the YouTube user's favourite music videos. Doxa. Comunicación 18, 83-104. http://bit.ly/perez-navarrete-gomez-2014. doi:10. 31921/doxacom.n18a4

PQ Media. (2018). Global Branded Entertainment Marketing Forecast 2018. http://bit.ly/ pqmedia-2018.

Sánchez-Olmos, C. (2018). Musicvertising in branded music content. An analysis of formats, features and sectors. Mediterranean Journal of Communication, 9(1), 305-319. http://bit.ly/sanchez-olmos-2018. doi:10.14198/MEDCOM2018.9.2.5

Smit, E., Van Reijmersdal, E., \& Neijens, P. (2009). Today's practice of brand placement and the industry behind it. International Journal of Advertising, 28(5), 761-782. doi:10. 2501/S0265048709200898 
Soba, M., \& Aydin, M. (2013). Product placement efficiency in marketing communication strategy. International Journal of Business \& Management, 8(12), 111-116. http://bit.ly/ soba-aydin-2013. doi:10.5539/ijbm.v8n12p111

Straw, W. (2001). Consumption. In S. Frith, W. Straw and J. Street (Eds.). The Cambridge companion to pop and rock. (pp. 53-90). Cambridge University Press. doi:10.1017/ CCOL9780521553698.005

Sung, Y., \& De Gregorio, F. (2008). New brand worlds: College student consumer attitudes toward brand placement in films, television shows, songs, and video games. Journal of Promotion Management, 14(1-2), 85-101. doi:10.1080/10496490802498272

Thornton, C., \& Burkhalter, J. (2015). Must be the music: examining the placement effects of character-brand association and brand prestige on consumer brand interest within the music video context. Journal of Promotion Management, 21(1), 126-141. doi:10.1080/ 10496491.2014.971212

Vernallis, C. (2004). Experiencing music video: Aesthetics and cultural context. Columbia University Press.

Viñuela, E. (2009). El videoclip en España (1980-1995) [Music video in Spain (1980-1995)]. ICCMU.

YouTube (2018). Most viewed videos of all time. http://bit.ly/top100videos-youtube. 